\title{
An example of niche partitioning between Dikerogammarus villosus and other invasive and native gammarids: a field study
}

\author{
Axel KLEY and Gerhard MAIER* \\ Department of Experimental Ecology of Animals, Section Limnology, University of Ulm, Albert-Einstein-Allee 11, 89069 Ulm, \\ Germany \\ *e-mail corresponding author: gerhard.maier@biologie.uni-ulm.de
}

\begin{abstract}
The invasive gammarid Dikerogammarus villosus is known to be a strong predator preying voraciously on a wide array of prey organisms including other gammarids. Predation by D. villosus on other gammarids is regarded as a main reason which led to the elimination of native and invasive gammarids in many reaches of European streams. At several sites in the River Danube and in a Rhine tributary, D. villosus was found co-existing with other gammarids. We studied whether predatory D. villosus is spatially segregated from other gammarids which would reduce predatory interactions. Two sites were investigated, one in the Danube (site 1) where D. villosus co-existed with the invasives Echinogammarus ischnus and Dikerogammarus bispinosus and another site in a Rhine tributary (site 2) where D. villosus co-existed with the invasive gammarid Echinogammarus berilloni and two native gammarids, Gammarus pulex and Gammarus roeseli. At site 1, D. villosus was spatially segregated from E. ischnus but not from D. bispinosus; E. ischnus lived at the uppermost shoreline in boulder substrate while Dikerogammarus spp. lived in greater depth in stony to gravelly substrate. At site 2, D. villosus prevailed in greater depth and gravelly to stony substrate where Corbicula molluscs were present while the other species lived in near-shore areas in macrophytes. Our results suggest that co-existence of predatory D. villosus with gammarids is possible by niche partitioning and that high habitat complexity as at site 2 facilitates co-existence. The fact that at site $1 \mathrm{D}$. bispinosus occupied approximately the same spatial niche than $\mathrm{D}$. villosus cannot be explained at present time.
\end{abstract}

Key words: Gammarids, invasive species, niche partitioning, Central Europe

\section{INTRODUCTION}

The Ponto-Caspian gammarid Dikerogammarus villosus SovINSKIJ invaded Central European waters in the last two decades and has displaced invasive and native gammarids in many reaches (e.g. Dick \& Platvoet 2000; Müller et al. 2002; Kley \& Maier 2003). Intraguild predation (IGP), i.e. predation between potential competitors which belong to the same guild, is widely accepted as a reason for species displacements (Dick 1992, 1996; MacNeil et al. 1997; Kinzler \& Maier 2003). Dikerogammarus villosus is known to be a strong predator preying voraciously on other gammarids (e.g. Dick \& Platvoet 2000; Kinzler \& Maier 2003). Although $D$. villosus is the prevailing and often the only gammarid in some Central European streams, it can be found coexisting with other invasive and/or native gammarids in certain reaches. For example, in the Main River, in southern Germany, D. villosus frequently coexists with another Ponto-Caspian gammarid, Echinogammarus ischnus STEBBING (Kley \& Maier 2003). Coexistence of $D$. villosus with other, less predatory gammarids may be possible by niche partitioning.

In this paper we investigate two sites, one site in the River Danube and another in a tributary of the Rhine River, where D. villosus coexisted with invasive (E. ischnus and Dikerogammarus bispinosus MARTINOV) and invasive (Echinogammarus berilloni CATTA) plus native gammarids (Gammarus pulex L. and Gammarus roeseli GERVAIS), respectively. We studied distribution of gammarids in different substrates and different depths. We expected that the predatory D. villosus is spatially segregated from the other gammarid species.

\section{DESCRIPTION OF SITES AND METHODS}

Both sites can be characterized as summer warm (maximum temperature $>24{ }^{\circ} \mathrm{C}$ in August) with a low current velocity $\left(<0.05 \mathrm{~m} \mathrm{~s}^{-1}\right)$ and a hard (total hardness 3.3-4.5 $\mathrm{mval} \mathrm{l}^{-1}$, conductivity $400-520 \mu \mathrm{S} \mathrm{cm}^{-1}$ ), nutrient and oxygen rich water (concentration of dissolved $\mathrm{PO}_{4}$ $\mathrm{P}=40-70 \mu \mathrm{g} \mathrm{l}^{-1} ; \mathrm{O}_{2}$ saturation $>75 \%$ ). Substrate at site 1 (Danube, Deggendorf) was composed of large boulders $(40 \times 40 \times 20 \mathrm{~cm})$ at the shoreline $(0-20 \mathrm{~cm}$ depth $)$ and gravelly substrate (grain size 1.0 to $5 \mathrm{~cm}$ ) in depths of 0.2-1.5 m; no aquatic vegetation was present. At site 2 (Rhine tributary) depths from 0.2 to $1 \mathrm{~m}$ were overgrown with aquatic plants (Fontinalis antipyretica L., Callitriche sp. and Elodea canadensis MiCHX). Substrate of near-shore areas (to a depth of approximately $0.2 \mathrm{~m})$ was also composed of large boulders $(40 \times 40 \times$ $20 \mathrm{~cm}$ ) followed by a mixture of gravel and larger stones (grain sizes between 1.0 to $15.0 \mathrm{~cm}$ ) in greater depth. The stony and gravelly substrate was covered by Corbicula molluscs at the greatest depth $(1.5 \mathrm{~m})$. At site $1 D$. villosus was the dominant amphipod in late spring and summer whereas at site 2 E. berilloni outnumbered 


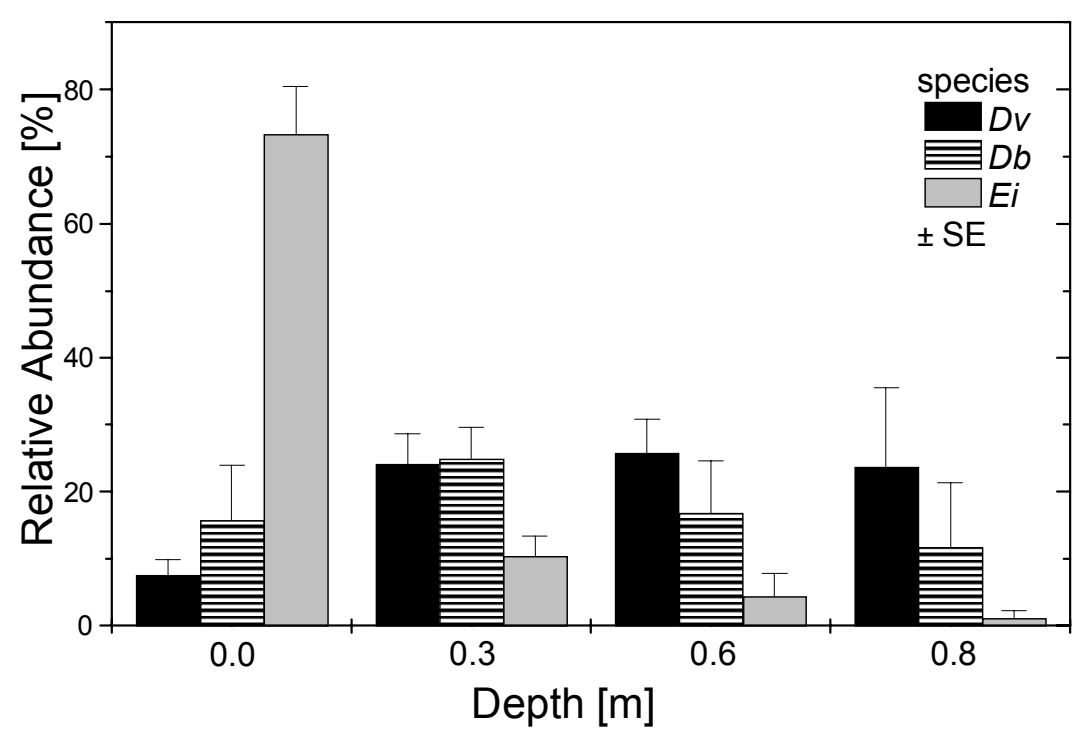

Fig. 1. Relative abundance of Dikerogammarus villosus (Dv), Dikerogammarus bispinosus (Db) and Echinogammarus ischnus (Ei) in different depths at site 1 (Danube, near Deggendorf, Germany).

D. villosus and the native species. Maximum abundance of D. villosus, E. ischnus and D. bispinosus at site 1 was 300,160 and 130 ind. $\mathrm{m}^{-2}$. At site 2 maximum abundance of E. berilloni was 200 ind. $\mathrm{m}^{-2}$ while maximum abundance of $D$. villosus and native species was $\leq 100$ ind. $\mathrm{m}^{-2}$. Dikerogammarus villosus was first recorded in the German Danube (near site 1) in the early 1990s (Tittizer et al. 1994); it has replaced native species which prevailed there until the late 1980s. The first appearance of $D$. villosus at site 2 is not known. However, as $D$. villosus was recorded in the Rhine since 1995 (Schöll et al. 1995; Bj De Vaate \& Klink 1995) it may be present at site 2 (Rhine tributary) since approximately the same time. Dikerogammarus villosus is the largest and heaviest gammarid species tested with an average fresh weight of $80 \mathrm{mg}$ in the male and $47 \mathrm{mg}$ in the female sex. Dikerogammarus bispinosus, E. ischnus and the native species $G$. roeseli were intermediate with 42 to $43 \mathrm{mg}$ in the male and 25 to $37 \mathrm{mg}$ in the female sex, respectively. Echinogammarus berilloni and $G$. pulex were smallest (25-30 mg in the male and 22-24 $\mathrm{mg}$ in the female sex).

Gammarids were collected from May $2^{\text {nd }}$ until March $4^{\text {th }}$ (Danube) and from May $2^{\text {nd }}$ to March $3^{\text {rd }}$ (tributary of Rhine River) in approximately monthly intervals at 4 (Danube) to 5 (Rhine tributary) different depths (Danube: near shore, 0.3, 0.6, $0.8 \mathrm{~m}$; Rhine tributary: near shore, $0.3,0.6,0.8,1.0 \mathrm{~m})$ and at 2 different substrates (site 1: boulders vs gravel and stones; site 2: stony substrate vs macrophytes). Sampling was not possible during some time in autumn/winter of 2002 because of the high water level. Different sampling technics and equipments (kick and pond net samples, turning over rocks, dislodging gammarids and rinsing them into a net), dependent on the substrate and depths, were employed to get representative numbers of gam- marids. Surber samplers were not used because the boulder substrate in near-shore areas made its use impossible. At each of the 12 (Danube) and 7 (Rhine tributary) sampling dates 1 to 3 areas of $0.5 \times 0.5 \mathrm{~m}$ per depth and substrate were carefully searched for gammarids. Sampling procedures were repeated until no more gammarids were obtained from the areas.

Since absolute abundances varied with time of the year, the relative abundance of each gammarid per depth and per substrate was calculated (total abundance in all depths/substrates $=100 \%$ ). A series of ANOVAs followed by Tukey's post hoc test served to test whether distribution of gammarids varied with the depth and the substrate.

\section{RESULTS}

Although there was a slight trend that gammarids were more evenly distributed during the cold than in the warm season, no significant difference in distribution of gammarids between different months could be observed (ANOVAs: Ps $=n s$ ); therefore, we pooled the data for different months.

At site 1, the relative abundance of E. ischnus varied with depth (ANOVA: $\mathrm{F}=52(3 / 55), \mathrm{P}<0.0001$ ); the highest densities were observed at the uppermost shoreline in boulder substrate (Fig. 1). No difference could be observed between different depths in relative abundance of D. villosus and D. bispinosus (ANOVAs: Ps $=\mathrm{ns}$ ). Both species were more evenly distributed than $E$. ischnus with a prevalence in gravelly substrate. There is a trend that $D$. villosus preferred greater depths than $D$. bispinosus.

At the second site, both substratum and depth affected the relative abundance of $D$. villosus (two-way ANOVA: Factor substratum: $\mathrm{F}=5.7(1 / 40), \mathrm{P}<0.02$; 

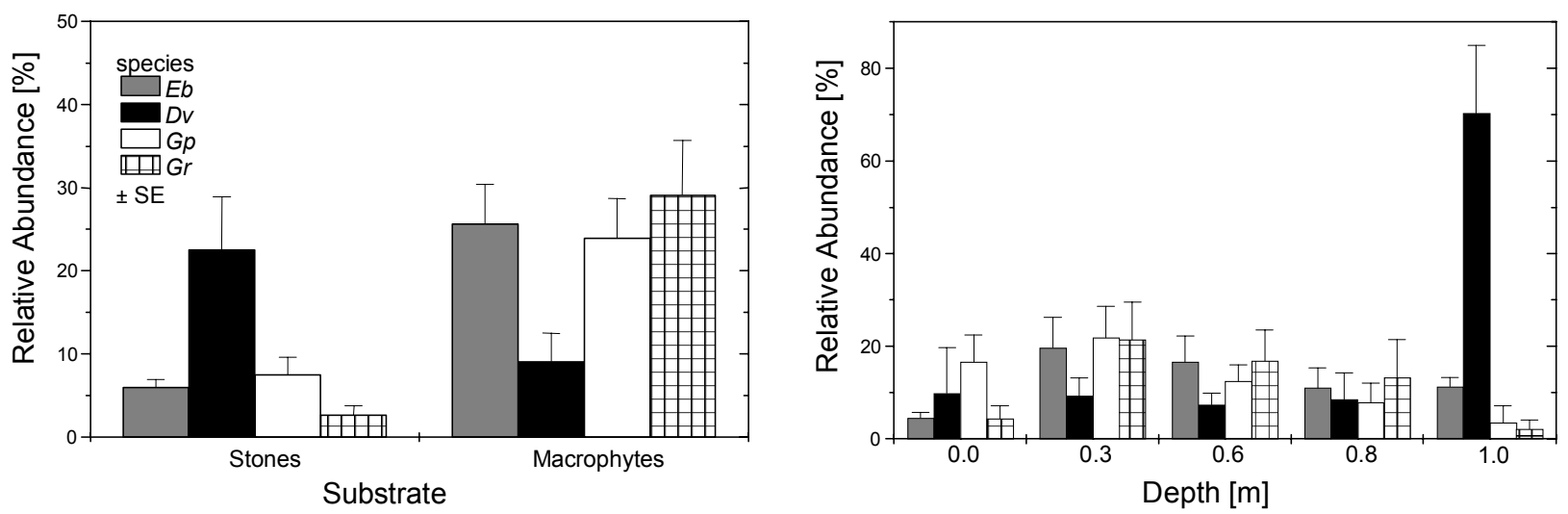

Fig. 2. Relative abundance of Dikerogammarus villosus (Dv), Echinogammarus ischnus (Ei), Gammarus pulex (Gp) and Gammarus roeseli $(\mathrm{Gr})$ in different substrates and different depth at site 2 (Rhine tributary).

factor depth: $\mathrm{F}=13.0(4 / 40), \mathrm{P}<0.0001)$. This species prevailed in stony substrate and in greater depths (Fig. 2). Relative abundance of E. berilloni, and of native species ( $G$. pulex and $G$. roeseli) were not affected by depth but significantly by substrate (two-way ANOVAs: Factor depth: Ps $=\mathrm{ns}$; factor substrate: $\mathrm{F}(1 / 40)=14.2$, 9.5 and 19.4 , Ps $=0.004$ to 0.0001$)$. The three species were more evenly distributed in all depths and prevailed in macrophytes.

\section{DISCUSSION}

Overlap of spatial niches can lead to biotic interactions, such as predation and/or competition. Predation by $D$. villosus on other gammarids (Dick \& Platvoet 2000; Kinzler \& Maier 2003) and on an array of other macroinvertebrates (Dick et al. 2002; Kelly et al. 2002; Krisp 2004) is regarded to pose a threat to the fauna of invaded ecosystems. Indeed, extinction of native gammarids and declines in the whole macroinvertebrate community have been observed in European streams coincidential with the arrival of $D$. villosus (van der Velde et al. 2000; Devin et al. 2001). However, recently MacNeil \& Platvoet (in prep.) have shown coexistence of $D$. villosus with other gammarids when habitat structures are complex. They further showed that IGP and cannibalism was reduced under complex habitat conditions.

The results of our study should be interpreted cautiously because of the shortcoming of our sampling procedures. Substrates varied with depths making sampling difficult (see Methods). In spite of these shortcomings, our results suggest niche partitioning between $D$. villosus and other gammarid species. At both sites D. villosus lived in places which were avoided by other gammarids. The only exception was $D$. bispinosus which lived in the same microhabitat as D. villosus at site 1 . We cannot interprete this at present time. However, the fact that abundance of $D$. bispinosus decreased to zero or almost zero when $D$. villosus reached its maximum abundance in May to July (Fig. 3) suggests that the lat- ter preyed heavily on the former. We cannot say why $D$. villosus lived in Corbicula banks at site 2. Possibly, the gammarid benefited by feeding on Corbicula faeces and prey organisms associated with the mussel (cf. Köhn \& Waterstraat 1990; van Overdijk et al. 2003).

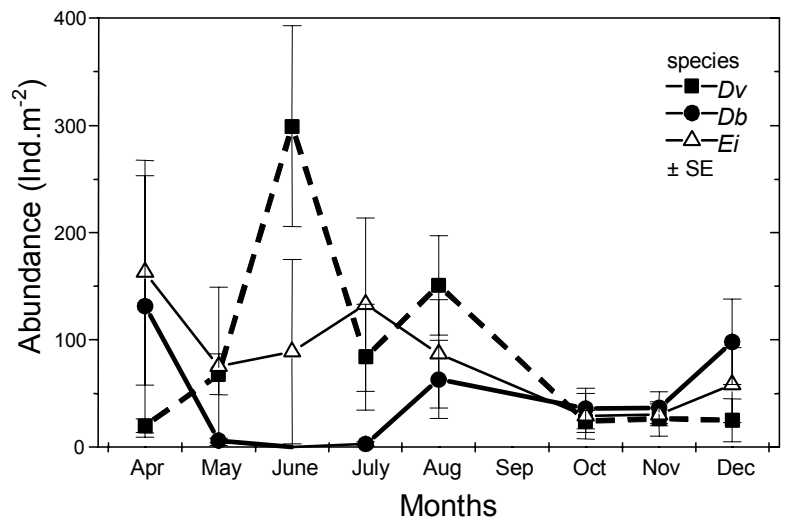

Fig. 3. Absolute abundance of Dikerogammarus villosus (Dv), Dikerogammarus bispinosus (Db) and Echinogammarus ischnus (Ei) at site 1.

It is also worthy to note that $G$. pulex which, like $D$. villosus, preferred stony substrate over macrophytes in laboratory experiments (Krisp 2004) was more numerous in macrophytes than in stones at site 2. Possibly $G$. pulex shifted from stony substrate to macrophytes to avoid contact with predatory D. villosus. Krisp (2004) showed in laboratory experiments that G. pulex shifted from stony substrate to macrophytes in the presence of D. villosus.

That no differences could be found in microhabitat use between native species and between E. berilloni and native species at site 2 can be an artefact. Possible differences may have been overlooked because quantitative sampling was difficult due to heterogenous substrates. 


\section{REFERENCES}

Bij De Vaate, A. \& A. Klink. 1995. Dikerogammarus villosus SoWINKSY (Crustacea: Gammaridae) - a new immigrant in the Dutch part of the Lower Rhine. Lauterbornia, 20: 5154.

Devin, S., C. Piscart, J.N. Beisel \& J.C. Moreau. 2003. Ecological traits of the amphipod invader Dikerogammarus villosus on a mesohabitat scale. Arch. Hydrobiol., 158: 4356.

Dick, J.T.A. 1992. The nature and implications of differential predation between Gammarus pulex and G. duebeni celticus (Crustacea: Amphipoda). J. Zool., London, 227: 171183.

Dick, J.T.A. 1996. Post-invasion amphipod communities of Lough Neagh, Northern Ireland: influences of habitat selection and mutual predation. J. Anim. Ecol., 65: 756-767.

Dick, J.T.A. \& D. Platvoet. 2000. Invading predatory crustacean Dikerogammarus villosus eliminates both native and exotic species. Proc. R. Soc. Lond. B, 267: 977-983.

Dick, J.T.A., D. Platvoet \& D.W. Kelly. 2002. Predatory impact of the freshwater invader Dikerogammarus villosus (Crustacea: Amphipoda). Can. J. Fish. Aquat. Sci., 59: 1078-1084.

Kelly, D.W., J.T.A. Dick \& W.I. Montgomery. 2002. Predation on mayfly nymph, Baetis rhodani, by native and introduced Gammarus: direct effects and the facilitation of predation by salmonids. Freshwat. Biol., 47: 1257-1268.

Kinzler, W. \& G. Maier. 2003. Asymmetry in mutual predation: possible reason for the replacement of native gammarids by invasives. Arch. Hydrobiol., 157: 473-481.

Kley, A. \& G. Maier. 2003. Life history characteristics of the invasive freshwater gammarids Dikerogammarus villosus and Echinogammarus ischnus in the River Main and the Main-Donau canal. Arch. Hydrobiol., 156: 457-469.

Köhn, J. \& A. Waterstraat. 1990. The amphipod fauna of Lake Kummerow (Mecklenburg, German Democratic Republic) with reference to Echinogammarus ischnus Stebbing, 1899. Crustaceana, 58: 74-82.

Krisp, H. 2004. Substratpräferenz, Aktivität Prädationsneigung und Wachstum von neozoischen und heimischen Gammaridenarten in Laborexperimenten. Diploma Thesis in Biology, University of Ulm, Germany: 67 pp.

MacNeil, C., J.T.A. Dick \& R.W. Elwood. 1997. The trophic ecology of freshwater Gammarus (Crustacea: Amphipoda); problems and perspectives concerning the functional feeding group concept. Biol. Rev. Cambridge Philosoph. Soc., 72: 349-364.

Müller, J.C., S. Schramm \& A. Seitz. 2002. Genetic and morphological differentiation of Dikerogammarus invaders and their invasion history in Central Europe. Freshwat. Biol., 47: 2039-2046.

Schöll, F., C. Becker \& T. Tittizer. 1995. Das Makrozoobenthos des schiffbaren Rheins von Basel bis Emmerich 1986-1995. Lauterbornia, 21: 115-137.

Tittizer, T., H. Leuchs \& M. Banning. 1994. Das Makrozoobenthos der Donau im Abschnitt Kehlheim - Jochenstein (Donau-km 2414-2202). Limnologie aktuell, 2, G. Fischer, Stuttgart: 173-188.

Van der Velde, G., S. Rajagopal, B. Kelleher, I.B. Musko \& A. bij de Vaate. 2000. Ecological impact of crustacean invaders: general considerations and examples from the Rhine River. In: von Vaupel Klein J.C. \& Schram F.R. (Eds), The biodiversity crisis and Crustacea. Proceedings of the Fourth International Crustacean Congress, Balkema Rotterdam, The Netherlands. Crustac. Issues 12: 3-33.

Van Overdijk, C.D.A., I.A. Grigorovich, T. Mabee, W.J. Ray, J.J.H. Ciborowski \& H.J. MacIsaac. 2003. Microhabitat selection by the invasive amphipod Echinogammarus ischnus and native Gammarus fasciatus in laboratory experiments and in Lake Erie. Freshwat. Biol., 48: 567578.

Received: July 2004

Accepted: February 2005 